\title{
Essential Oils and Their Application on Active Packaging Systems: A Review
}

\author{
Maria Carpena ${ }^{1,2} \oplus$, Bernabe Nuñez-Estevez ${ }^{1,2}\left(\right.$, Anton Soria-Lopez ${ }^{1}$, Paula Garcia-Oliveira ${ }^{1,2}(\mathbb{0}$ \\ and Miguel A. Prieto $1,2, * \mathbb{D}$ \\ 1 Nutrition and Bromatology Group, Analytical and Food Chemistry Department, \\ Faculty of Food Science and Technology, University of Vigo, Ourense Campus, E-32004 Ourense, Spain; \\ maria.carpena.rodriguez@uvigo.es (M.C.); bernabenunez16@gmail.com (B.N.-E.); \\ antonsoria@hotmail.es (A.S.-L.); paula.garcia.oliveira@uvigo.es (P.G.-O.) \\ 2 Centro de Investigação de Montanha (CIMO), Instituto Politécnico de Bragança, Campus de Santa Apolonia, \\ 5300-253 Bragança, Portugal \\ * Correspondence: mprieto@uvigo.es
}

Citation: Carpena, M.;

Nuñez-Estevez, B.; Soria-Lopez, A.; Garcia-Oliveira, P.; Prieto, M.A.

Essential Oils and Their Application on Active Packaging Systems:

A Review. Resources 2021, 10, 7.

https://doi.org/10.3390/

resources 10010007

Received: 1 November 2020

Accepted: 13 January 2021

Published: 17 January 2021

Publisher's Note: MDPI stays neutral with regard to jurisdictional clai$\mathrm{ms}$ in published maps and institutional affiliations.

\section{Copyright: (C) 2021 by the authors. Li-} censee MDPI, Basel, Switzerland. This article is an open access article distributed under the terms and conditions of the Creative Commons Attribution (CC BY) license (https:// creativecommons.org/licenses/by/ $4.0 /)$.

\begin{abstract}
The food industry is continuously evolving through the application of innovative tools and ingredients towards more effective, safe, natural and ecofriendly solutions to satisfy the demands of the costumers. In this context, natural sources (i.e., leaves, seeds, peels or unused pulp) can entail a valuable source of compounds, such as essential oils (EOs), with recognized antioxidant and antimicrobial properties that can be used as natural additives in packaging applications. The current trend is the incorporation of EOs into diverse kinds of biodegradable materials, such as edible films, thus developing active packaging systems with improved preservation properties that can offer benefits to both the food and packaging industry by reducing food waste and improving the management of packaging waste. EOs may be added into the packaging material as free or encapsulated molecules, where, especially this last option, has been revealed as very promising. The addition of these lipophilic compounds provides to the end-product various bioactivities of interest, which can eventually extend the shelf-life of the product by preventing food spoilage. Pairing biodegradable packaging with EOs extracted from natural agro-industrial by-products can lead to a more sustainable food industry. Recent knowledge and advances on this issue will be reviewed in the present work.
\end{abstract}

Keywords: food waste; packaging; circular economy; essential oils; preservation

\section{Introduction}

Packaging is essential for protecting food products from the environment and is intended to ensure food safety at the same time that industrial and consumer requirements are satisfied [1]. Researchers have investigated new advances on packaging systems, leading to the development of active packaging. This is one of the most promising fields in the packaging sector, which aims to prolong shelf life, ensure food quality and safety and improve product appearance [2]. Active packaging materials are characterized by incorporating components with biological properties that are slowly released into the food product [3]. According to the Regulation 1935/2004/EC and the Regulation 450/2009/EC, active materials in which the active packing is included are referred to as "materials and articles that are intended to extend the shelf-life or to maintain or improve the condition of packaged food" $[4,5]$. Several examples of active packaging systems include oxygen and carbon dioxide scavengers, but also emitters of flavor, aroma and other compounds. Among these molecules, those that have biological properties are considered target compounds, since they can enhance the shelf-life of the food products [6,7].

Alternatively, numerous studies have demonstrated that plants and other natural sources such as leaves, seeds, peels or unused pulp from food industry, may be a valu- 
able and efficiently source of compounds such as polyphenols, flavonoids, tocopherols, pigments or essential oils (EOs) with biological properties [7-9]. All these molecules have been reported as potential candidates to be included in active packaging systems. In particular, EOs are well known for their bioactive molecules, volatiles and antioxidant and antimicrobial properties but their use has been limited as a consequence of their strong flavor [7].

EOs are secondary metabolites synthesized by plants. As many other secondary metabolites, they possess different bioactivities that have been employed for centuries by utilizing the whole plant or by the application of the EOs previously extracted. Traditionally, they have been used mostly for pharmacological, medicinal, aromatic or cosmetic purposes. However, from the 19th century, their application has been wider in the nutritional field [10]. Many different EOs have been characterized, even though the chemical profile depends on the species, the collection area and season or the extraction solvents and techniques. Their physical properties prompt their use in the food industry since they contain volatile aroma compounds, they are commonly liquid and colorless at room temperature, they are lipophilic and they can create emulsions with hydrophilic solvents. Further, they possess several bioactivities, such as antimicrobial, antifungal, antioxidant, antiviral, antiparasitic or insecticidal. Thus, these compounds have been used in the food industry as aroma and flavor ingredients, but also for preservative purposes [11-14]. The possibility of developing active packaging systems containing natural bioactive compounds such as EOs is a promising alternative since it can reduce food safety risks associated with chemically synthetized additives [1].

Currently, EOs application in active food packaging are strongly linked to their incorporation into biodegradable films in combination with another polysaccharide-proteinor lipid-based edible film [15]. Another recent approach is the development of composite films or multicomponent films to take advantage of their main beneficial properties [16].

Hence, the incorporation of EOs is increasingly common, because they can enhance antimicrobial and antioxidant activity, among others, or reduce water vapor permeability [17]. Particularly, when producing biofilms, hydrophilic matrices are usually used (for increasing water vapor permeability), formed by protein or polysaccharides polymers that serve as a base on which to incorporate other substances such as lipid components [18]. Ideally, for this purpose, the chosen materials should be of low viscosity, with high hygroscopicity and emulsifying capacity, low reactivity, low cost and with no effect on organoleptic properties of the processed food $[19,20]$. Specifically, lipophilic substances, such as EOs, incorporated into hydrophilic materials is performed by the application of emulsification or homogenization [21]. Thus, the association of EOs and biodegradable films is gaining more attention, especially by the active food packaging industry.

Therefore, the objective of this manuscript is to review the potential of using EOs in active packaging to extend food shelf life, preservation and other properties and also, to provide an overview of current trends in their use in packaging. Briefly, the methodology applied restricted bibliography to the last 5-10 years and the search of information followed the final structure of the manuscript using different key words such as "EOs", "active packaging" or "food applications".

\section{Application of Essential Oils in Food Preservation and Packaging Sector}

Most of the permitted food additives are applied for their preservation properties, attributed to their recognized bioactivities. Additives with antimicrobial properties can control food spoilage and/or prevent contamination by foodborne pathogens, including acetic, malic, lactic, benzoic, sorbic and propionic acids, potassium and calcium acetates, carbon dioxide, benzoates, sorbates, propionates, nitrites, nitrates or parabens. The most used additives that prevent food browning, caused by chemical or enzymatic reactions, are sulfites. Even though all these compounds are permitted to be used in the food industry, the current trend is replacing chemically synthesized compounds for natural ones. In this sense, the use of EOs is considered as an alternative to the use of synthetic additives [3,22]. 
In active packaging, the packaging materials can incorporate components with biological properties destined to be slowly released into the food [3] (Figure 1). The use of EOs in appropriate amounts may improve the water vapor barrier property and also provide antioxidant and antimicrobial activity to the packaging films.

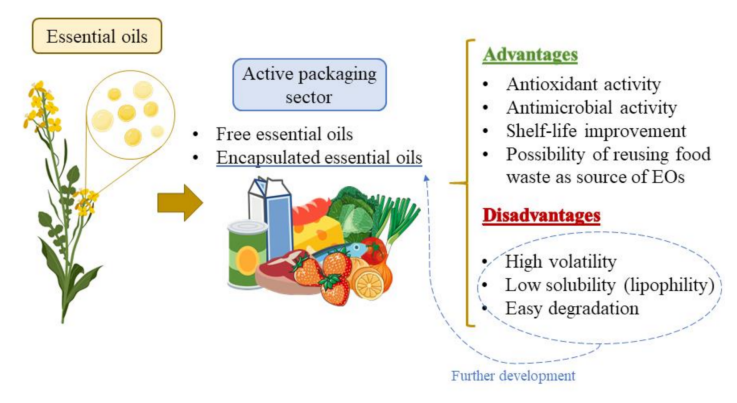

Figure 1. Essential oils (EOs) application strategies in the food active packaging sector: advantages and disadvantages.

In fact, the antimicrobial properties of EOs (together with antioxidant activity) have been analyzed in several studies where they have been found to be efficient against a wide range of food-borne pathogens [23,24]. Particularly, the antimicrobial effects of EOs are frequently associated with their hydrophobic/lipophilic character that allows them to permeate through membranes and their layers [25]. Table 1 presents some of the most studied compounds detected in different EOs (terpenes, terpenoids, phenols, esters, aromatic compounds, aldehydes, lactones, ketones are within these molecules) which have been demonstrated to have antimicrobial effects [10]. These antimicrobial attributes have prompted their use in active packaging to preserve food quality and extend the shelf-life of the final product [26].

Table 1. Different classes of compounds present in EOs with reported antimicrobial activity, characteristics and examples of some of them. Based on [26-30].

\begin{tabular}{|c|c|c|c|}
\hline Chemical Class & Characteristics & Examples & $\begin{array}{c}\text { Example of Chemical } \\
\text { Structure }\end{array}$ \\
\hline Hydrocarbons & $\begin{array}{l}\text { - Their basic structures are } \\
\text { 5-carbon-based units (isoprenes) } \\
\text { - They act as major compounds }(90 \%)\end{array}$ & $\begin{array}{c}\text { Citronellol, limonene, } \\
\alpha \text {-pinene, camphor, myrcene, } \\
\text { E- } \beta \text {-Ocimene }\end{array}$ & (Limonene) \\
\hline Phenols & $\begin{array}{l}\text { - They include phenolic terpenoids } \\
\text { - They are aromatic components } \\
\text { among the most reactive }\end{array}$ & $\begin{array}{l}\text { Carvacrol, eugenol, thymol, } \\
\text { chavicol }\end{array}$ & (Thymol) \\
\hline Esters & - Pleasant smell & $\begin{array}{c}\text { Eugenol acetate, geranyl } \\
\text { acetate, linalyl acetate, bornyl } \\
\text { acetate }\end{array}$ & (Eugenol acetate) \\
\hline Alcohols & $\begin{array}{l}\text { - Pleasant aromas and no reported } \\
\text { contraindications }\end{array}$ & $\begin{array}{l}\text { Linalool, menthol, borneol, } \\
\text { santalol, nerool, citronellol, } \\
\text { generaniol, terpineol, } \\
\text { pinocarveol }\end{array}$ & (Linallol) \\
\hline Volatile compounds & - They include aromatic compounds & $\begin{array}{l}p \text {-cymene, } \gamma \text {-terpinene, } \\
\text { camphene, etc. }\end{array}$ & $(p$-cymene $)$ \\
\hline Aldehydes & $\begin{array}{l}\text { - They are unstable and are oxidized } \\
\text { easily } \\
\text { - Derived from spices and fruits } \\
\text { (aromatic compounds) }\end{array}$ & $\begin{array}{l}\text { Benzaldehyde, citronellal, } \\
\text { cinnamaldehyde, myrtenal, } \\
\text { citral, citronellal }\end{array}$ & (Citronellal) \\
\hline
\end{tabular}


Regarding natural antioxidants, most of them are phenolic compounds, which prevent oxidation through the scavenging of free superoxide and hydroxyl radicals. The mechanism of action of this reaction consists on a proton donation by the phenolic compound inducing their own oxidation, and then get stabilized their polarity by electron dislocation [31,32]. An example of this reaction is shown with carvacrol (a component highly present in EOs) as an antioxidant molecule (Figure 2).

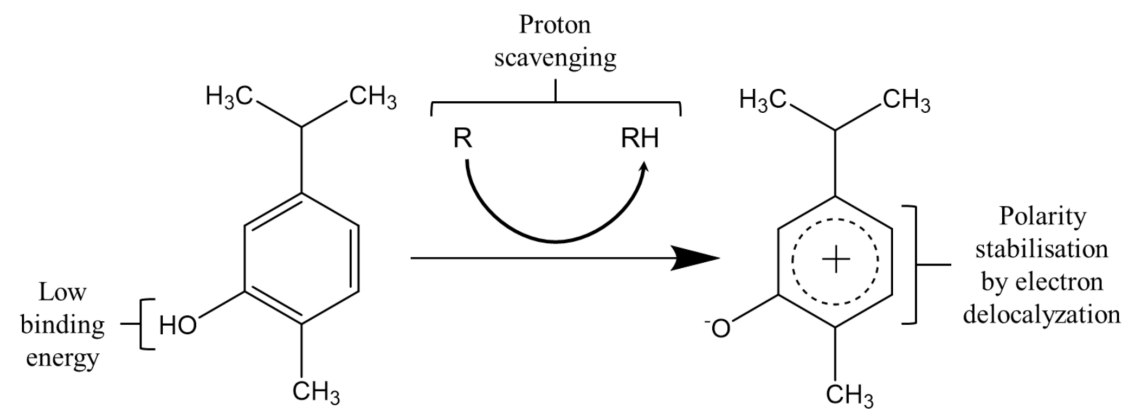

Figure 2. Carvacrol proton donation. This reaction results in the antioxidant bioactivity of phenolic compounds.

In vitro antioxidant capacity may be measured by determining the oxidation rate of several chemicals, like DPPH (2,2'-diphenyl-2-picrylhydrazyl), TBARS (2-thiobarbituric acid substances) or AAPH (2,2'-azobis(2-methylpropionamidine) dihydrochloride) when exposed to potential antioxidants [33]. Regarding food oxidation spoilage, TBARS is a useful indicator to evaluate lipid oxidation, while other methods may include determination of metmyoglobin formation percentage in meats and free fatty acids content, which indicates the polyunsaturated fatty acids (PUFAs) oxidation degree [34,35]. Running these tests could provide a wider spectrum of information of the activities of the compounds of interest and how the oxidation of food products takes place.

While research often focuses on isolated phenolic compounds as potential additives (as they are well-known, potent antioxidants and generally account for low toxicity), these same compounds are present at proper concentrations in EOs extracted from plants and thus can be used to provide extra properties to biodegradable materials such as biofilms [36,37]. EOs do not only have the specific phenolic compounds of each species, but also valuable volatile and aromatic compounds [28].

In active packaging applications, EOs have been applied in different ways, free and encapsulated, both in non-degradable and biodegradable materials.

\subsection{Free EOs Combined with Packaging Materials}

Free EOs have been combined with different biodegradable materials, such as paper or edible films. Cardboard and paper have been traditionally used as packaging material but new packaging systems such as active cardboard tray coated with emulsions including encapsulated EOs are continuously being developed. These are widely used as food and vegetables packaging material (with waterproof layers) and are considered as an alternative to the high use of plastics by the packaging sector $[38,39]$. However, due to the water vapor permeability of these materials, it is convenient and necessary to apply a layer of some material that makes them resistant to the presence of water, vapors and gases. EOs are an attractive alternative for the creation of such films, due to their waterproofing properties and biological activities, turning packaging into an active material and increasing its value. For example, eugenol (a common component of EOs) was linked to cellulose by polycarboxylic acid to create a paper-based active packaging. This new material was used to pack wheat flour and other grain foods and prevented water absorption similarly to typical packaging paper and preserved the mechanical properties of the grain products, although ductility and tensile strength were reduced. Besides, it significantly provided insecticide 
and insectifuge capacities, which extended the product shelf life without compromising its original flavor, taste and odor [40].

Regarding edible films, EOs are added into a hydrophilic matrix resulting in an aqueous dispersion. In this way, the lipid droplets become embedded in the matrix once the film is subjected to a drying process causing structural reorganizations of the hydrophilic components [41,42]. For instance, in a study performed on a chitosan-based film, as the formed dispersion loses water through drying, the concentration of lipid particles increases, which also increases the risk of emulsion phases separation, flocculation or loss of EOs. In particular, the stability of the film microstructure can be improved by application of microfluidization which entails a reduction of the droplet size and the viscosity of the aqueous phase, also resulting in an increase of the $\zeta$-potential, which indicates that the emulsion can be stable against aggregation events [43]. Few studies have displayed the advantages of using EOs as an additional ingredient directly added to the edible films or biodegradable trays to enhance their packaging properties. Syzygium aromaticum EOs were incorporated into two kinds of edible films, one elaborated with gelatin and other with a mixture of gelatin and chitosan. Both materials containing the EOs showed significant anti-bacterial activity, especially against Gram-negative bacteria, when tested in chilled fish samples [44]. Another work used cassava bagasse and polyvinyl alcohol to create biodegradable trays containing EOs from Origanum vulgare or Eugenia caryophyllata (Syzygium aromaticum). The EOs were incorporated into the trays in two ways: directly, by adding them into the mixture of ingredients or by coating the surfaces with EOs. The best results were achieved when trays were coated with the highest amount of EOs, showing inhibitory effects against different bacterial and fungi species [45]. Other biodegradable films containing EOs have been tested in different food matrices such as fruits (i.e., strawberries), prolonging their shelf-life but also preventing or reducing the growth of bacterial colonies and acting as fungicides [46]. Additionally, the active biodegradable films containing encapsulated EOs showed no cytotoxicity while they permitted to maintain the sensorial properties of the food products during storage [47].

\subsection{Encapsulation of EOs}

Encapsulation is an affordable and ideal technique to protect EOs from limiting factors, including oxidative processes, photodegradation, thermal conditions or high relative humidity. Encapsulation also provides a controlled release of the EO from the capsule which can last up to 45 days [48]. Encapsulation also favors the incorporation of fats in the different matrices utilized for creating packaging materials, since it reduces the negative interactions between the lipid phase and the matrix, whose nature is normally hydrophilic. Therefore, the use of encapsulated lipophilic molecules prevents the alteration of the properties of the final structure of the packaged product [49]. In addition, this technique is useful to prevent changes in the organoleptic properties of the food product caused by EOs and other lipids $[39,50]$.

Basically, capsules can be classified into three large groups according to their size: macrocapsules, microcapsules and nanocapsules. The latter present a diameter between 0.05 and $1 \mu \mathrm{m}$, although the most common average measure is between 0.1 and $0.5 \mu \mathrm{m}$ [51]. The use of capsules with diameters in the nanoscale range is more convenient since the particle size is inversely proportional to the stability, that is, the smaller the diameter of the capsules, the greater the stability during incorporation into the matrices. Likewise, a better control of its availability and release is also achieved, favoring the creation of active packaging systems that prolong food shelf-life. Active packaging can be developed by the direct incorporation of the nanocapsules into the matrix of the packaging material or they can be emulsified in an aqueous base to make a waterproofing barrier to cover the package [22,52-54].

Several studies have assessed the suitability of EOs' encapsulation and different encapsulation materials. For instance, rosemary EO was successfully encapsulated in a benzoic acid-chitosan nanogel that was lately included in the starch-carboxy methyl 
cellulose film [55]. Other study used zein to synthesize a film containing microencapsulated rose hip seed EOs and the protective properties of this material were evaluated in bananas and cumquats. Negative controls, in both kinds of fruit, showed discoloration and signs of rotting with storage time, but when packaged in zein-rose hip EO film, spoilage slowed down [56]. Lectin was employed to encapsulate different concentrations of Thymus zygis EO $(0.25$ to $0.5 \mathrm{~g} / \mathrm{g}$ polymer $)$ to optimize the EO retention. The best approach provides a $45-55 \%$ of EO retention which improved the antifungal activity of the film, its water barrier capacity, gloss and resistance [57]. Cyclodextrins, which have been extensively studied in recent years, have been used to encapsulate EOs. A work presented a successful solution for the encapsulation of EOs extracted from coriander by combining them with cyclodextrins. This mixture allowed the encapsulation of the coriander EO, which becomes further stabilized by their inclusion in dextrin-derived nanosponges. This final product permitted the development of a controlled release mechanism stable at high temperature. Thus, the encapsulation of the EO allowed extending the action time of the bioactivities associated to the major biocompounds present in coriander [58]. Another study analyzed the encapsulation efficiency of different concentrations of cinnamon EO (0.5 to $3 \mathrm{~g})$ and $\beta$-cyclodextrin (1 to $3 \mathrm{~g}$ ). Then, an electro spun nanofibrous film was developed using the electrospinning polyvinyl alcohol to which it was added $\beta$-cyclodextrin and cinnamon EO. When this film was tested with strawberries showed a prolonged shelf-life of the product while maintaining its sensorial properties during storage. The shelf-life of strawberries was similar to that achieved with common plastic film but the nanofibrous film presented two additional features: it was non-toxic and biodegradable [46]. EOs are a current field of study in the food packaging sector that could compete with the actual materials of food packaging for its enormous versatility and possibilities that need to be more explored.

Conserving the bioactivities of EOs presents a challenge that needs to be addressed. The concentration of EOs extracts needed to maintain their bioactivities in the food could alter the organoleptic characteristics of the food making it less attractive to the consumer. This makes the use of EOs at industrial scale difficult. Furthermore, the use of encapsulated EOs has shown some physical modifications such as plasticizing effect or tensile and color properties variations [3,59-61].

\section{Current Trends on the Application of EOs in the Food Industry}

Currently there is a growing interest in the production of active packaging using renewable and environmentally friendly materials [62]. Innovative active packaging has been shown to extend the shelf life of food products and reduce the growth rate of certain microorganisms. These improvements can be achieved through the formation of biocomposite systems based on natural biopolymers or synthetic materials.

Some articles have stated that edible packaging has gained popularity within consumers, since an edible film or coating, apart from prolonging the shelf-life of the food product, can also be consumed together with the food [26]. On the other hand, other studies have highlighted that few cases of films can be really eaten (whereas others can only be more easily degraded) and that consumers will only accept edible films if they feel them as safe [63]. These packaging systems can incorporate components intended to be immobilized at the film, released into food or able to absorb substances responsible for spoilage [64]. Among other things, packaging protects food from dehydration and acts as a gas barrier from the surrounding media. Edible films can serve as carriers of active compounds such as antimicrobials, antioxidants, texture enhancers or key nutrients, among others [65]. Furthermore, these properties can be enhanced by incorporating active substances to the films such as EOs.

EOs can be incorporated in food and beverage packaging systems (edible films) as an additional ingredient directly added to edible films or encapsulated into the edible films. For instance, different amounts of EOs from Origanum vulgare and Eugenia caryophyllata were incorporated into cassava bagasse-polyvinyl alcohol-based trays. EOs were incorporated into the trays in two ways, directly by adding them into the mixture of ingredients at 
proportions $6.5,8.5$ and $10.0 \%(w / w)$ or by coating the surface with EOs at concentrations $2.5,5.0$ and $7.5 \mathrm{~g}$ oil $/ 100 \mathrm{~g}$ tray. The best results were achieved when trays were coated with the highest amounts of EOs, especially for O. vulgare that displayed total inhibition of molds, yeasts and few Gram-positive and negative bacteria, showing total inhibition or important reduction of the bacterial viability [45].

Hence, EOs exhibit antimicrobial and antioxidant characteristics while they are compatible with several types of food, contributing to the increase of food products shelf life or enhancing their organoleptic properties $[10,43]$. In the United States, several EOs that have already been used in food packaging have been recognized as safe ingredients and included in the Generally Recognized as Safe (GRAS) category established by the Food and Drug Administration (FDA) [17]. However, it must also be considered that they are chemically unstable and easily oxidized, being sensitive to light, oxygen and temperature changes. In this sense, nanoencapsulation techniques can be used to improve EOs chemical stability and enhance their physicochemical capabilities, thus allowing their use in food packaging [66]. For example, fish oil was encapsulated by emulsion electrospinning into polyvinyl alcohol nanofibers. The encapsulation efficiency for high omega- 3 fatty acids $(92.4 \pm 2.3 \%)$ provided an oil load capacity of $11.3 \pm 0.3 \%$ and thus, an even distribution of oil into the fibers and fortification of the food matrix with less amounts of PUFAs [67]. The type and amount of EOs incorporated into the packaging material will provide specific biological activity [68].

Some of the most commonly EOs used in packaging systems have been extracted from jasmine, rosemary, peppermint, cinnamon, oregano, thyme, cumin, eucalyptus, rosewood, clove, tea tree, palmarosa, geranium, lavender, lemongrass, mandarin, bergamot or lemon. With respect to the food matrixes on which packaging systems with EOs have been used, different food products such as fresh meat, butter, fresh octopus, ham and fish can be found [3]. Regarding their major identified components, they belong to the hydrocarbon monoterpenes, such as $\alpha$-pinene, $\beta$-pinene, $\alpha$-selinene and $p$-cymene, or to the oxygenated monoterpenes group, such as thymol, carvacrol, geraniol, borneol, eugenol, linalool, terpineol-4-ol, 1,8-cineole, $\alpha$-terpinyl acetate and camphor [13-15,49]. Another study evaluated variable concentrations of some major hydrocarbon and oxygenated monoterpenes present in EOs. These compounds applied at a concentration of $0.2 \mu \mathrm{g} / \mathrm{mL}$ and a pH 4.0 showed antibacterial effect against E. coli and L. monocytogenes. This work underlined that oxygenated monoterpenes exerted more effective antimicrobial effect than hydrocarbon ones. In fact, the efficiency of these molecules was evaluated in orange or apple juice in combination with heat treatments and displayed synergistic lethal effect against E. coli. [14].

Thus, the aim of food packaging regarding biodegradable materials in combination with EOs is to perform antioxidant and antimicrobial assays to evaluate the final packaging system in contact with the food matrix to provide robust results. Table 2 summarizes some of the recent assays using films with incorporated EOs for new packaging systems in the food industry.

Table 2. Recent examples of active films containing EOs as main constituents showing beneficial properties for the packaged food product.

\begin{tabular}{cccc}
\hline Film & EOs & Food & Main Results \\
\hline Gelatin & $\begin{array}{c}\text { Orange (Citrus sinensis } \\
\text { (L.) Osbeck) EO }\end{array}$ & $\begin{array}{c}\text { Pink shrimp } \\
\text { (Parapenaeus } \\
\text { longirostris) }\end{array}$ & $\begin{array}{c}\text { Antioxidant and antimicrobial activity } \\
\text { Extension of shelf-life of nearly 10 days }\end{array}$ \\
\hline [69] \\
Gelatin- & Oregano EO & $\begin{array}{c}\text { Refrigerated Rainbow } \\
\text { Trout Fillets }\end{array}$ & $\begin{array}{c}\text { Lowering of total volatile basic nitrogen, } \\
\text { peroxide value, thiobarbituric acid and } \\
\text { microbial growth }\end{array}$ \\
\hline
\end{tabular}


Table 2. Cont.

\begin{tabular}{|c|c|c|c|c|}
\hline Film & EOs & Food & Main Results & Ref. \\
\hline $\begin{array}{l}\text { Gelatin-carboxymethyl } \\
\text { cellulose-chitin } \\
\text { nanofibers- }\end{array}$ & $\begin{array}{l}\text { Trachyspermum ammi } \\
\text { EO (Ajowan) }\end{array}$ & Refrigerated raw beef & $\begin{array}{l}\text { Growth inhibition of Pseudomonas spp., } \\
\text { S. aureus, lactic acid bacteria (LAB), molds } \\
\text { and yeasts. Stability of the chemical } \\
\text { profile, color and sensory properties }\end{array}$ & [71] \\
\hline Curdlan-PVA & Thyme EO & Chilled meat & $\begin{array}{l}\text { Improvement of antioxidant activity and } \\
\text { extension of the shelf life }\end{array}$ & [72] \\
\hline Chitosan-cassava starch & $\begin{array}{c}\text { Myrcia ovata } \\
\text { Cambessedes EOs }\end{array}$ & Mangaba fruits & $\begin{array}{c}\text { Antimicrobial effect against Bacillus cereus, } \\
\text { B. subtilis and Serratia marcescens }\end{array}$ & [73] \\
\hline Chitosan & $\begin{array}{l}\text { Cumin EO } \\
\text { nanoemulsion }\end{array}$ & Refrigerated beef loins & $\begin{array}{l}\text { Growth inhibition of mesophilic and } \\
\text { psychrophilic bacteria, Enterobacteriaceae } \\
\text { and LAB. Antioxidant effects. }\end{array}$ & [74] \\
\hline Chitosan & Clove EO & Cooked pork sausages & $\begin{array}{l}\text { Microbial growth inhibition, retarded } \\
\text { lipid oxidation and shelf-life extension } \\
\text { when refrigerated storage }\end{array}$ & [75] \\
\hline Chitosan beads & $\begin{array}{l}\text { Lavender or red thyme } \\
\text { EOs }\end{array}$ & Strawberry (clamshell) & $\begin{array}{l}\text { Antifungal effect against Botrytis cinerea. } \\
\text { Maintenance of appearance, color and } \\
\text { firmness but odor, flavor and overall } \\
\text { acceptability decrease }\end{array}$ & [76] \\
\hline $\begin{array}{l}\text { Chitosan and whey } \\
\text { protein }\end{array}$ & $\begin{array}{c}\text { Garlic EO } \\
\text { nanoencapsulated }\end{array}$ & $\begin{array}{l}\text { Vacuum-packed } \\
\text { sausages }\end{array}$ & $\begin{array}{l}\text { Retarded lipid oxidation and growth } \\
\text { inhibition of main spoilage bacterial }\end{array}$ & [77] \\
\hline Whey protein isolate & Oregano and garlic EOs & Kasar cheese slices & $\begin{array}{l}\text { Antimicrobial effect against Escherichia } \\
\text { coli, Salmonella enteritidis, } \\
\text { Listeria monocytogenes, } \\
\text { Staphylococcus aureus and Penicillium spp. }\end{array}$ & [78] \\
\hline $\begin{array}{l}\text { Whey protein } \\
\text { isolate-cellulose } \\
\text { nanofibers }+\mathrm{TiO}_{2} \\
\text { nanoparticles }\end{array}$ & Rosemary EO & Refrigerated lamb meat & $\begin{array}{c}\text { Increase of the shelf life and antimicrobial } \\
\text { effect against Pseudomonas spp., } \\
\text { Enterobacteriaceae, LAB, S. aureus, } \\
\text { L. monocytogenes and E. coli }\end{array}$ & [79] \\
\hline Pectin & $\begin{array}{l}\text { Oregano } \mathrm{EO}+ \\
\text { resveratrol } \\
\text { nanoemulsion }\end{array}$ & Fresh pork loin & $\begin{array}{l}\text { Lowering pH effect, color change, } \\
\text { retarded lipid and protein oxidation, } \\
\text { microbial growth inhibition under high } \\
\text { oxygen modified atmosphere packaging }\end{array}$ & [80] \\
\hline Sodium alginate & Citral and Eugenol EOs & $\begin{array}{l}\text { Arbutus unedo L. Fresh } \\
\text { fruit }\end{array}$ & $\begin{array}{c}\text { Improvement of postharvest quality } \\
\text { attributes during storage. Reduction of } \\
\text { microbial growth }\end{array}$ & [81] \\
\hline Sodium caseinate & $\begin{array}{c}\text { Ginger EO } \\
\text { nanoemulsion }\end{array}$ & Chicken breast fillets & $\begin{array}{l}\text { Growth inhibition of total aerobic } \\
\text { psychrophilic bacteria }\end{array}$ & [82] \\
\hline $\begin{array}{l}\text { Arabic gum- sodium } \\
\text { caseinate }\end{array}$ & $\begin{array}{l}\text { Cinnamon or } \\
\text { lemongrass EO }\end{array}$ & Guava fruit & $\begin{array}{l}\text { Browning and related enzymes decrease, } \\
\text { higher acceptability, antioxidant activity } \\
\text { and high content of phenolic compounds }\end{array}$ & [83] \\
\hline
\end{tabular}

\subsection{Antimicrobial Activity of EOs in Food Systems}

To understand the interest on the enhancement of antimicrobial activity of packaging, some facts are needed to be mentioned. First, numerous investigations have been carried out to improve the quality and safety of products during storage without using synthetic additives and opting for other alternatives which are claimed to maintain their nutritional and organoleptic properties while controlling food-borne pathogens. However, packaging is still needed to avoid microbial contamination. The application of EOs to biodegradable materials (edible films) show potential for solving these problems since they could avoid or lower the use of synthetic preservatives $[3,66,84]$. Table 3 presents EOs with an antimicrobial effect against specific foodborne pathogenic bacterial species (Campylobacter jejuni, 
Escherichia coli, Listeria monocytogenes, Salmonella enterica, Staphylococcus aureus). In a study of Settanni et al., 2012, it was stated that lemon EO was able to inhibit the 42 strains of L. monocytogenes with a minimum inhibitory concentration (MIC) of $0.156 \mu \mathrm{L} / \mathrm{mL}$ and the 35 strains of $S$. aureus with a dose of $0.039 \mu \mathrm{L} / \mathrm{mL}$ [9]. Another study revealed that the bactericidal activity of cinnamon with respect to E. coli, S. enterica, C. jejuni and L. monocytogenes, was more effective than the EOs of oregano and eugenol [85]. A recent study analyzed the antimicrobial activity of EOs obtained from different sources such as Syzygium aromaticum L., Foeniculum vulgare Miller, Cupressus sempervirens L., Lavandula angustifolia, Thymus vulgaris L., Verbena officinalis L., Pinus sylvestris and Rosmarinus officinalis. Data showed that the most effective EO was the one extracted from $S$. aromaticum L., followed by EOs from $R$. officinalis and L. angustifolia, while P. sylvestris and F. vulgare Miller displayed the poorest antimicrobial activity [44]. In the same experimental work, they analyzed the antibacterial effect of S. aromaticum L. EO when incorporated into two kinds of edible films, one based on gelatin and the other based on gelatin-chitosan. The antibacterial activity of the edible films containing S. aromaticum L. EO was demonstrated against E. coli, Lactobacillus acidophilus, Listeria innocua and Pseudomonas fluorescens [44]. Another study found that an edible film whey protein based with incorporated oregano or clove EOs was able to protect chicken breast fillets against food spoilage microorganisms such as aerobic mesophilic and psychrotrophic bacteria, LAB and Pseudomonas spp. [86].

Table 3. EOs and EO components effective against some common food-borne bacteria. Information collected from $[9,26,78,79,85,87]$.

\begin{tabular}{|c|c|c|c|c|c|}
\hline \multirow{2}{*}{ EOs/Components } & \multicolumn{5}{|c|}{ Bacterial Species } \\
\hline & CJ & EC & $\mathbf{L M}$ & SE & SA \\
\hline Cinnamaldehyde, thymol, carvacrol, perillaldehyde, eugenol, estragole & + & + & + & + & \\
\hline Oregano, cinnamon, thyme, bay leaf, allspice, clove bud oils & & + & + & + & \\
\hline Palmarosa oil, salicylaldehyde, geraniol, isoeugenol & & + & & + & \\
\hline $\begin{array}{l}\text { Ginger root, marigold, jasmine, carrot seeds, celery seeds, mugwort, spikenard, } \\
\text { orange bitter oil, benzaldehyde, citral, carvone R, geranyl acetate }\end{array}$ & + & & & & \\
\hline Lemongrass oil, citral & & + & & & \\
\hline Patchouli, gardenia, cedarwood oils & + & & + & & \\
\hline Citral, geraniol, carvone S, salicylaldehyde & & & + & & \\
\hline Marjoram oil, terpineol & & & & + & \\
\hline Lemon EO & & & + & + & + \\
\hline Melissa and lemon oils, terpineol, geraniol, linalool & & & & + & \\
\hline Rosemary EO & & + & + & & + \\
\hline Oregano and garlic EOs & & + & + & + & + \\
\hline
\end{tabular}

CJ: Campylobacter jejuni; EC: Escherichia coli; LM: Listeria monocytogenes; SE: Salmonella enterica; SA: Staphylococcus aureus; +: active against bacterial species.

Another comparative study analyzed some hydrocarbons and oxygenated monoterpenes commonly present in EOs extracted from eucalyptus, lavender, orange, peppermint, pine and rosemary. Among others, $\alpha$-pinene, $\beta$-pinene and p-cymene, thymol, carvacrol, borneol, linalool, terpineol-4-ol, 1,8-cineole, $\alpha$-terpinyl acetate and camphor were analyzed in terms of their antimicrobial capacity. They all showed bactericidal effect $(0.2 \mu \mathrm{g} / \mathrm{mL}$ and $\mathrm{pH} 4.0$ ) against $E$. coli and L. monocytogenes and oxygenated monoterpenes were more effective than hydrocarbon monoterpenes [14].

However, the in vitro antimicrobial capacity of EOs is not always maintained when incorporated into in real food products. This is due to the interactive effects of several factors that are characteristic of food. Different factors can modify the interaction between food and the biomolecules embedded in packaging such as the $\mathrm{pH}$, water activity, 
additives, salt, fat and protein content, specific of each kind of food product, and also extrinsic determinants, such as the temperature of storage and the composition of the atmosphere [88].

\subsection{Antioxidant Activity of EOs in Food Systems}

Food spoilage is mainly a result of reactions that take place when food comes in contact with oxygen or through the action of spoilage microorganisms [89]. Oxidative damage is caused by the interactions of reactive oxygen species (ROS) with any compound susceptible to be oxidized and suffer structural changes in the process. Superoxide radicals $\left(\mathrm{O}_{2}{ }^{2-}\right)$, hydroxyl radicals $\left(\mathrm{OH}^{-}\right)$and hydrogen peroxide $\left(\mathrm{H}_{2} \mathrm{O}_{2}\right)$ are classified under the category of ROS [90]. Yet, ROS also exert several undesirable and significant changes in foods such as limiting their shelf-life, lowering nutritional value, loss of color, flavor and odor. All these changes result in, for example, food rancidity [37]. The major parameter responsible for rancidity is the oxidation and peroxidation of fatty acids and other fats present in foods. In packed foods, this process is generally considered to be initiated by change in metals' oxidation state already present in food and/or exposure to light containing ultraviolet (UV) (such as sunlight), which leads to subsequent hydrogen abstraction from fats and in turn, causes successive reactions in adjacent fat molecules [91]. As a side effect of this process, ketones and toxic aldehydes may also be produced [89]. Moisture also plays a determinant role in oxidation, as it may provide ROS derived from the water content of the food product. Additionally, as oxidative reactions take place during time, several molecules (sugars, short chain fatty acids) become more easily available to spoilage organisms and thus, the food surface becomes more favorable to them. In the same way, foods are susceptible to oxidation or enzymatic activity and ROS liberation. Thus, oxidative damage and microbial growth are the most significant causes of food spoilage [3].

One strategy to avoid the interaction between ROS and foods is the exclusion of oxygen using thermoplastic films in packaging [18]. However, this method generates non-degradable packaging waste and many new laws are being proposed to reduce or permanently ban these single-use plastics [92]. New alternatives are being explored to replace the use of synthetic antioxidant compounds. In this context, the incorporation of EOs to films could solve both issues, the reduction of plastic packages and the lowering use of synthetic additives.

The use of hydrophobic oleic films, in combination with other polymers, to coat food products has been demonstrated to significantly delay oxidation [93]. Hence, different vegetable matrices known for their antioxidant properties have been tested as potential new sources of EOs that could be combined with other compounds to develop new active food films. Therefore, EOs of savory spices and herbs, which are known to present high levels of phenolic compounds, are of special interest to be used in active food packaging, since they also add desirable flavor and aromas [94]. Some of the most prominent are oregano, thyme, rosemary, cinnamon or basil, whereas also isolated compounds from varying sources may be included into the packaging film, like $\alpha$-tocopherol or $\beta$-carotene [3,94]. Recent findings are presented in Table 4 where the antioxidant capacity induced by the combination of different films and EOs (with major compounds identified when possible) was assessed in different food matrices.

For instance, in fish skin gelatin films loaded with different citrus EOs, it was found that water vapor permeability was reduced until $2.81 \times 10^{-11} \mathrm{gm}^{-1} \mathrm{~s}^{-1} \mathrm{~Pa}^{-1}$, whereas antioxidant capacity was also higher in the films with EOs, showing better results for DPPH, FRAP and ABTS assays. In this particular case, the EOs were mixed with Tween 20 at $25 \%$ and then incorporated into film solution at 50\% [12,95]. The transfer of EOs from the package is highly influenced by the quantity and distribution of fats present in specific food products. The diffusion of the EOs compounds from packaging is greater towards the lipid matrices. However, foods of high fat content will have an uneven distribution of EOs compounds, since EOs can get trapped in the lipid fraction of the food instead of being distributed uniformly [96]. Likewise, higher lipid content on the part of the packaging 
material manages to retain the preservative compounds for a longer time. In these cases, migration occurs more slowly, achieving a gradual, prolonged and efficient diffusion [97].

Table 4. Antioxidant capacity evaluated using different food matrixes by the combination of diverse films and EOs (implicated bioactive compounds identified when possible) through several antioxidant assays.

\begin{tabular}{|c|c|c|c|c|c|}
\hline Food & Film Polymers & Identified Compounds & Source of EOs & Antioxidant Assays & Ref. \\
\hline Lamb & Polyethylene/polyamide & - & Oregano, rosemary & TBARS, metmyoglobin & [98] \\
\hline Foal & Polyethylene & $\begin{array}{c}\text { r-cymene, d-limonene, } \\
\text { camphor, borneol, thymol, } \\
\text { carvacrol, [ . . . ] }\end{array}$ & Oregano & TBARS, metmyoglobin & [99] \\
\hline Beef & Soy protein & - & Oregano, thyme & DPPH, TBARS, Rancimat & [100] \\
\hline - & $\begin{array}{l}\text { Rice starch/fish muscle } \\
\text { protein }\end{array}$ & - & Oregano & $\mathrm{DPPH}$ & [101] \\
\hline Smoked sardine & Gelatin (pigskin)/chitosan & $\mathrm{tPC}$ & Oregano, rosemary & FRAP, FFA & [102] \\
\hline- & Quince seed mucilage & $\mathrm{tPC}$ & Oregano & $\mathrm{DPPH}$ & [103] \\
\hline- & Hake muscle protein & $\begin{array}{c}\text { Propenyldisulfide, thymol, } \\
\text { carvacrol }[\ldots]\end{array}$ & Oregano, clove, garlic & $\mathrm{DPPH}$ & [104] \\
\hline Pork sausage & - & - & Rosemary & TBARS & [105] \\
\hline Poultry & Chitosan/montmorillonite & - & Rosemary & TBARS & [106] \\
\hline Eel & CMC & $\begin{array}{c}\text { tPC, rosmarinic acid, } \\
\text { isorhamnetin-3-O- hexoside } \\
{[\ldots]}\end{array}$ & Rosemary & DPPH & [107] \\
\hline Swordfish & LDPE/polyamide & Carvacrol, thymol & Rosemary & TBARS $[\ldots]$ & [108] \\
\hline- & Quince seed mucilage & tPC & Thyme & $\mathrm{DPPH}$ & [109] \\
\hline Chicken sausage & LPDE/nylon & $\mathrm{tPC}$ & Thyme, clove & DPPH, TBARS & [110] \\
\hline Cut peach & Pectin & $\begin{array}{l}\text { Eugenol, cinnamaldehyde } \\
{[\ldots]}\end{array}$ & Cinnamon & $\mathrm{DPPH}$ & [111] \\
\hline Pork & Chitosan/LDPE & - & Cinnamon & POV, TBARS & [112] \\
\hline Sweet pepper & Chitosan & - & Cinnamon & $\begin{array}{l}\text { TBARS, catalase and } \\
\text { peroxidase activity }\end{array}$ & [113] \\
\hline Rainbow trout & Gelatin & - & Cinnamon & FFA, TBARS & [114] \\
\hline Rainbow trout & Chitosan & - & Cinnamon & POV, TBARS & [115] \\
\hline- & Whey protein & $\mathrm{tPC}, \mathrm{tFC}$ & $\begin{array}{l}\text { Rosemary, cinnamon, } \\
\text { basil }\end{array}$ & ABTS, $\beta$-carotene bleaching & [116] \\
\hline Oat, linoleic acid & HDPE, LDPE, EVA & Sesamol & Sesame & Hexanal retention & [117] \\
\hline Barley soup & - & $\begin{array}{c}\text { DL-Limonene, } \gamma \text {-terpinene, } \\
\text { tri-cyclene }[\ldots]\end{array}$ & Lemon peel & $\mathrm{DPPH}$ & [118] \\
\hline Grapes & Chitosan/glycerol & $\mathrm{tPC}$ & Bergamot & DPPH & [119] \\
\hline- & Chitosan/gelatin & $\beta$-carotene & Commercial isolate & $\mathrm{DPPH}$ & [120] \\
\hline Sunflower oil & Cassava starch, LDPE & $\beta$-carotene & Carrots & POV & [121] \\
\hline- & Polyethylene/polypropylene & $\alpha$-tocopherol & Commercial isolate & DPPH, ABTS & [122] \\
\hline Salmon & LDPE & $\alpha, \gamma, \delta$-tocopherols & Commercial isolate & DPPH, TBARS & [123] \\
\hline- & LDPE/polypropylene & $\alpha, \gamma, \delta$-tocopherol & Soybean & Conjugated dienes & [124] \\
\hline Butter & Chitosan/glycerol & $\alpha$-tocopherol & Commercial isolate & DPPH & [125] \\
\hline
\end{tabular}

-: Not described; [ ... ]: Others; tPC: total phenolic compounds measured, but not determined; tFC: total flavonoids content; DPPH: 2,2'Diphenyl-2-picrylhydrazyl-hydrate free radical assay; TBAR: 2-thiobarbituric acid reductive value assay; FRAP: ferric reducing antioxidant power assay; ABTS: 2,2'-azino-bis(3-ethylbenzothiazoline-6-sulfonic) acid assay; FFA: free fatty acid determination; POV: peroxide value; CMC: carboxy-methyl-cellulose; EVA: ethylene vinyl acetate; LDPE: low density polyethylene; HDPE: high density polyethylene.

Oregano EO is well known for its antiseptic properties and may be the most extensively researched herb regarding this field. So, many different studies have been carried out with diverse blends and films in order to test the effectiveness of its preserving properties [126,127]. Research assessing this EO has been conducted on lamb, foal or beef meat, 
reporting significant delays in oxidation ( $2-4$ days) compared with control samples. The activity of oregano $\mathrm{EO}$ has also been tested in edible blends such as starch, animal protein or cellulosic fibers $[101,103]$. Moreover, it seems that some blends with just $1 \%$ of oregano EO exert antioxidant and antimicrobial activities $[127,128]$. Similar results have been obtained with thyme. This could be explained because thyme and oregano share thymol and carvacrol as their major phenolic compounds [100]. Thyme EO has been applied for example to beef and swordfish meats $[100,108]$. Cinnamon EO has also been researched because of its documented bioactive properties, independent of the blend used, and very popular flavor [113]. Cinnamon EO has been tested to delay decomposing and oxidation in fresh fruit and vegetables [46,111,113] and pork or fish meats [112,114,115,129]. In the case of rosemary EO, it has been noted that the phenolic compound rosmarinic acid, a very effective antioxidant, is present at high levels. Hence, its antioxidant potential has been researched upon with several meats $[98,105]$ and fish [102,107]. Notably, rosemary EO has even shown higher antioxidant activity than conventional antioxidants like butylated hydroxytoluene (BHT) [36,105].

Given the evidence supported by these reports, EOs should be considered as adequate antioxidants, which in turn would give added value to the herbs or organic waste from which they can be extracted. However, despite the antioxidant activity of EOs, they must be combined with other materials not to allow oxygen passage [91]. Several biodegradable and/or edible biopolymers like starch films, cellulosic fibers or chitosan are being profiled as suitable alternatives to thermoplastics [130], while animal-derived polymers like gelatin (collagen matrix) or muscle protein are being considered as well [95,131]. Moreover, the conjugation of these EOs with different polymer nanoparticles or formulated in emulsions seems to be a promising choice for coating foods, aside of the packaging film employed [132].

\subsection{Flavors and Aromas Transference in Active Food Packaging}

Flavors and aromas are added to food to enhance their taste and odor, but in the case of active packaging applied with EOs they are not incorporated for enhancing food properties. In fact, the strong and intense odor of EOs might end up transferring some unwanted taste to the packed food when used with preservation purposes. Further, they contain volatile components that are easily evaporated. Hence, the nanoencapsulation of EOs represent a useful technique to mask their odor and flavor and prevent their evaporation. The encapsulation enhances flavor properties and reduces EOs impact on the organoleptic characteristics of the food. It also improves EOs solubility in water-soluble polymers and provides effective releasing properties and better distribution [21]. Thus, nanoencapsulated materials need to have a low reactivity with EOs and no influence on the organoleptic characteristics of the packed food. For instance, eugenol applied to a cellulose material was used to pack grain foods. It preserved the organoleptic properties of the original product while improving the insecticide properties of the package [40]. Cinnamon EO was also included into a polyvinyl alcohol nanofibrous films that allowed masking its intense flavor while providing antibacterial activity against Gram-positive and Gran-negative bacteria. This strategy is effective in extending the shelf-life of quickly perishable fruits, like strawberries [14]. Furthermore, depending on the properties of the compounds or EOs to be nanoencapsulated, different materials can be used. Lately, the use of biopolymers and biocomposites has been addressed as useful materials for their environmentally friendly characteristics: their biocompatibility, their low toxicity and their biodegradability [21].

\section{Legislation of EOs in Food}

The legal framework that concerns the use of EOs in food involves two approaches, the use of EOs as a food ingredient, that represent an additional nutrient to ingest, or the use of EOs as part of the packaging. In the first scenario, EOs must obey food legislation applied in each region. Depending on the aim of its application, different legislations will apply. EOs will be considered additives when they represent a "substance not normally 
consumed as a food in itself and not normally used as a characteristic ingredient of food, whether or not it has nutritive value, the intentional addition of which to food for a technological purpose in the manufacture, processing, preparation, treatment, packaging, transport or storage of such food results, or may be reasonably expected to result, in it or its by-products becoming directly or indirectly a component of such foods" [5]. In the Annex III of the Commission Regulation (EU) No 1130/2011, rosemary extracts are considered as additives. However, no other references to some of the main components of EOs have been found as additives [133]. In the second case, when EOs are treated as flavoring substances, they are considered "products not intended to be consumed as such, which are added to food in order to impart or modify odor and/or taste; or products made or consisting of the following categories: flavoring substances, flavoring preparations, thermal process flavorings, smoke flavorings, flavor precursors or other flavorings or mixtures thereof" [134]. However, in the list of flavoring substances provided by Regulation (EC) No 2232/96, few of the major compounds identified in EOs have been found, such as eugenol, carvacrol, thymol or terpineol, among others [135]. Nevertheless, no limits or indications are presented in this document since it suggests consulting the additional information into EFSA's Compendium of Botanicals. The aim of this compendium is to provide information to improve the safety assessment of botanical products and preparations intended for use in food [136]. Nonetheless, the use of botanicals and derived preparations in food has to comply with the general requirements set out in Regulation (EC) No 178/2002, which lays down the general principles and requirements of food law in the EU [137].

The second scenario includes the treatment of EOs as part of the material intended to contact food. In this case, the developed material has to mainly comply with the Regulation (EC) 1935/2004 that regulates the materials and articles intended to come into contact with food [138] and the Regulation (EC) 2023/2006 that complements the previous one, since it regulates the good manufacturing practices for materials and articles intended to come into contact with food [139]. In the case of United States, the FDA collects in the Code of Federal Regulations a list of EOs, oleoresins and natural extracts for their intended use. Additionally, FDA has recognized some EOs as flavoring agents in food such as linalool, thymol, eugenol, vanillin, carvacrol and limonene [140,141].

\section{Conclusions}

EOs have been demonstrated to exert different biological activities although antioxidant and antimicrobial properties are the most highlighted. Thus, they could prevent the deterioration caused by oxidation and microbial spoilage in food products. Considering this, they could be incorporated into active packaging materials. In fact, several studies have evaluated the effectiveness of using EOs, as part of the active packaging material, in very different foods matrices. Regarding the different application methods, encapsulation is considered as a suitable technique since it reduces several disadvantages of EOs.

At last, vegetable sources can be considered as reservoirs of bioactive compounds, in some cases EOs. The extraction, obtaining and incorporation of these EOs into new packaging systems such as biodegradable films could be an alternative option in food packaging industry. According to the revised literature, some lines need to be further studied and developed: more studies are necessary to evaluate the effects of adding EOs into new packaging systems regarding their mechanical, organoleptic and biological properties as well as to ensure their safety and lack of side effects for the consumers and the environment. Finally, market studies are strongly recommended before the commercialization of new active packaging materials and the use of EOs to know the acceptance of consumers to these new products. 
Author Contributions: Formal analysis, M.C., B.N.-E., A.S.-L.; P.G.-O. and M.A.P.; investigation, M.C., B.N.-E., A.S.-L.; P.G.-O. and M.A.P.; methodology, B.N.-E., A.S.-L.; M.C., P.G.-O. and M.A.P.; supervision, M.A.P.; validation, M.A.P.; writing—original draft, M.C., B.N.-E., A.S.-L.; P.G.-O. and M.A.P.; writing-review and editing, M.A.P. All authors have read and agreed to the published version of the manuscript.

Funding: The research leading to these results received financial support from: Programa de Cooperación Interreg V-A España_Portugal (POCTEP) 2014-2020 (projects Ref.: 0181_NANOEATERS_01_E and Ref: 0377_IBERPHENOL_6_E); Xunta de Galicia for the Axudas Conecta Peme supporting the IN852A 2018/58 NeuroFood Project; EcoChestnut Project (Erasmus + KA202) supporting the work of M. Carpena; to Ibero-American Program on Science and Technology (CYTED-AQUA-CIBUS, P317RT0003); Xunta de Galicia for the program EXCELENCIA-ED431F 2020/12; Bio Based Industries Joint Undertaking (JU) under grant agreement No 888003 UP4HEALTH Project (H2020-BBI-JTI-2019), the JU receives support from the European Union's Horizon 2020 research and innovation program and the Bio Based Industries Consortium.

Institutional Review Board Statement: Not applicable.

Informed Consent Statement: Not applicable.

Data Availability Statement: Not applicable. No new data were created or analyzed in this study. Data sharing is not applicable to this article.

Acknowledgments: MICINN supporting the Ramón and Cajal grant for M.A. Prieto (RYC-201722891); to EcoChestnut Project for supporting the grant of M. Carpena; to Xunta de Galicia and University of Vigo for supporting the pre-doctoral grant of P. García-Oliveira (ED481A-2019/295). The project SYSTEMIC " an integrated approach to the challenge of sustainable food systems: adaptive and mitigatory strategies to address climate change and malnutrition", Knowledge hub on Nutrition and Food Security has received funding from national research funding parties in Belgium (FWO), France (INRA), Germany (BLE), Italy (MIPAAF), Latvia (IZM), Norway (RCN), Portugal (FCT), and Spain (AEI) in a joint action of JPI HDHL, JPI-OCEANS and FACCE-JPI launched in 2019 under the ERA-NET ERA-HDHL (n ${ }^{\circ}$ 696295).

Conflicts of Interest: The authors declare no conflict of interest.

\section{Abbreviations}

$\begin{array}{ll}\text { Generic } & \\ \text { EO(s) } & \text { Essential oil(s) } \\ \text { ROS } & \text { Reactive oxygen species } \\ \text { UV } & \text { Ultraviolet } \\ \text { FDA } & \text { Food and Drug Administration } \\ \text { GRAS } & \text { Generally recognized as safe } \\ \text { MIC } & \text { Minimum inhibitory concentration } \\ \text { LAB } & \text { Lactic Acid Bacteria } \\ \text { Compounds } \\ \text { PUFAs } & \text { Polyunsaturated fatty acids } \\ \text { HDPE } & \text { High density polyethylene } \\ \text { LDPE } & \text { Low density polyethylene } \\ \text { CMC } & \text { Carboxymethyl cellulose } \\ \text { BHT } & \text { Butylated hydroxytoluene } \\ \text { PLA } & \text { Polylactic acid } \\ \text { Techniques } \\ \text { tPC } & \text { Total phenolic compounds } \\ \text { tFC } & \text { Total flavonoids content } \\ \text { FFA } & \text { Free fatty acid determination } \\ \text { POV } & \text { Peroxide value } \\ \text { DPPH } & \text { 2,2-diphenyl-1-picryl-hydrazyl-hydrate free radical assay } \\ \text { TBARS } & \text { 2-thiobarbituric acid reductive value assay } \\ \text { FRAP } & \text { Ferric reducing antioxidant power assay } \\ \text { ABTS } & \text { 2,2'-azino-bis(3-ethylbenzothiazoline-6-sulfonic) acid assay }\end{array}$




\section{References}

1. Sharma, S.; Barkauskaite, S.; Jaiswal, A.K.; Jaiswal, S. Essential oils as additives in active food packaging. Food Chem. 2020, 343, 128403. [CrossRef] [PubMed]

2. Fang, Z.; Zhao, Y.; Warner, R.D.; Johnson, S.K. Active and intelligent packaging in meat industry. Trends Food Sci. Technol. 2017, 61, 60-71. [CrossRef]

3. Ribeiro-Santos, R.; Andrade, M.; de Melo, N.R.; Sanches-Silva, A. Use of essential oils in active food packaging: Recent advances and future trends. Trends Food Sci. Technol. 2017, 61, 132-140. [CrossRef]

4. Restuccia, D.; Spizzirri, U.G.; Parisi, O.I.; Cirillo, G.; Curcio, M.; Iemma, F.; Puoci, F.; Vinci, G.; Picci, N. New EU regulation aspects and global market of active and intelligent packaging for food industry applications. Food Control 2010, 21, 1425-1435. [CrossRef]

5. European Parliament and the Concil of the European Union. Regulation (EC) No 1333/2008 of the European Parliament Ans of the Council of 16 December 2008 on Food Additives; European Parliament and the Concil of the European Union: Belgium, Brussel, 2008; pp. 16-33.

6. European Parliament and Council. Directive 2008/98/EC of the European Parliament and of the Council of 19 November 2008 on Waste and Repealing Certain Directives (Waste Framework); European Parliament and Council: Brussels, Belgium, 2008 ; pp. 3-30.

7. Kehili, M.; Choura, S.; Zammel, A.; Allouche, N.; Sayadi, S. Oxidative stability of refined olive and sunflower oils supplemented with lycopene-rich oleoresin from tomato peels industrial by-product, during accelerated shelf-life storage. Food Chem. 2018, 246, 295-304. [CrossRef] [PubMed]

8. Putnik, P.; Bursać Kovačević, D.; Režek Jambrak, A.; Barba, F.J.; Cravotto, G.; Binello, A.; Lorenzo, J.M.; Shpigelman, A. Innovative "Green" and Novel Strategies for the Extraction of Bioactive Added Value Compounds from Citrus Wastes-A Review. Molecules 2017, 22, 680. [CrossRef] [PubMed]

9. Settanni, L.; Palazzolo, E.; Guarrasi, V.; Aleo, A.; Mammina, C.; Moschetti, G.; Germanà, M.A. Inhibition of foodborne pathogen bacteria by essential oils extracted from citrus fruits cultivated in Sicily. Food Control 2012, 26, 326-330. [CrossRef]

10. Burt, S. Essential oils: Their antibacterial properties and potential applications in foods-A review. Int. J. Food Microbiol. 2004, 94, 223-253. [CrossRef]

11. Hyldgaard, M.; Mygind, T.; Meyer, R. Essential Oils in Food Preservation: Mode of Action, Synergies, and Interactions with Food Matrix Components. Front. Microbiol. 2012, 3, 12. [CrossRef] [PubMed]

12. Falleh, H.; Ben Jemaa, M.; Saada, M.; Ksouri, R. Essential oils: A promising eco-friendly food preservative. Food Chem. 2020, 330, 127268. [CrossRef]

13. Rota, M.C.; Herrera, A.; Martínez, R.M.; Sotomayor, J.A.; Jordán, M.J. Antimicrobial activity and chemical composition of Thymus vulgaris, Thymus zygis and Thymus hyemalis essential oils. Food Control 2008, 19, 681-687. [CrossRef]

14. Ait-Ouazzou, A.; Cherrat, L.; Espina, L.; Lorán, S.; Rota, C.; Pagán, R. The antimicrobial activity of hydrophobic essential oil constituents acting alone or in combined processes of food preservation. Innov. Food Sci. Emerg. Technol. 2011, 12, 320-329. [CrossRef]

15. Mohamed, S.A.A.; El-Sakhawy, M.; El-Sakhawy, M.A.M. Polysaccharides, Protein and Lipid-Based Natural Edible Films in Food Packaging: A Review. Carbohydr. Polym. 2020, 238, 116178. [CrossRef]

16. Hassan, B.; Chatha, S.A.S.; Hussain, A.I.; Zia, K.M.; Akhtar, N. Recent advances on polysaccharides, lipids and protein based edible films and coatings: A review. Int. J. Biol. Macromol. 2018, 109, 1095-1107. [CrossRef] [PubMed]

17. Kouhi, M.; Prabhakaran, M.P.; Ramakrishna, S. Edible polymers: An insight into its application in food, biomedicine and cosmetics. Trends Food Sci. Technol. 2020, 103, 248-263. [CrossRef]

18. Atarés, L.; Chiralt, A. Essential oils as additives in biodegradable films and coatings for active food packaging. Trends Food Sci. Technol. 2016, 48, 51-62. [CrossRef]

19. Blanco-Padilla, A.; Soto, K.M.; Hernández Iturriaga, M.; Mendoza, S. Food antimicrobials nanocarriers. Sci. World J. 2014, 2014, 1-11. [CrossRef]

20. Zhu, G.; Xiao, Z.; Zhou, R.; Yi, F. Fragrance and flavor microencapsulation technology. Adv. Mater. Res. 2012, 2, 440-445. [CrossRef]

21. Burgos, N.; Mellinas, A.C.; García-Serna, E.; Jiménez, A. Nanoencapsulation of Flavor and Aromas in Food Packaging; Elsevier Inc.: Philadelphia, PA, USA, 2017.

22. Carocho, M.; Barreiro, M.F.; Morales, P.; Ferreira, I.C.F.R. Adding molecules to food, pros and cons: A review on synthetic and natural food additives. Compr. Rev. Food Sci. Food Saf. 2014, 13, 377-399. [CrossRef]

23. Salehi, B.; Sharopov, F.; Martorell, M.; Rajkovic, J.; Ademiluyi, A.O.; Sharifi-Rad, M.; Fokou, P.V.T.; Martins, N.; Iriti, M.; Sharifi-Rad, J. Phytochemicals in Helicobacter pylori infections: What are we doing now? Int. J. Mol. Sci. 2018, $19,2361$. [CrossRef]

24. Mahomoodally, F.; Aumeeruddy-Elalfi, Z.; Venugopala, K.N.; Hosenally, M. Antiglycation, comparative antioxidant potential, phenolic content and yield variation of essential oils from 19 exotic and endemic medicinal plants. Saudi J. Biol. Sci. 2019, 26, 1779-1788. [CrossRef]

25. Hassoun, A.; Carpena, M.; Prieto, M.A.; Simal-Gandara, J.; Özogul, F.; Özogul, Y.; Çoban, Ö.E.; Guðjónsdóttir, M.; Barba, F.J.; Marti-Quijal, F.J.; et al. Use of spectroscopic techniques to monitor changes in food quality during application of natural preservatives: A review. Antioxidants 2020, 9, 882. [CrossRef] [PubMed] 
26. Jugreet, B.S.; Suroowan, S.; Rengasamy, R.R.K.; Mahomoodally, M.F. Chemistry, bioactivities, mode of action and industrial applications of essential oils. Trends Food Sci. Technol. 2020, 101, 89-105. [CrossRef]

27. Djilani, A.; Dicko, A. The Therapeutic Benefits of Essential Oils. In Nutrition, Well-Being and Health; Books on Demand: Norderstedt, Germany, 2012; pp. 155-178.

28. Bhavaniramya, S.; Vishnupriya, S.; Al-Aboody, M.S.; Vijayakumar, R.; Baskaran, D. Role of essential oils in food safety: Antimicrobial and antioxidant applications. Grain Oil Sci. Technol. 2019, 2, 49-55. [CrossRef]

29. Tohidi, B.; Rahimmalek, M.; Trindade, H. Review on essential oil, extracts composition, molecular and phytochemical properties of Thymus species in Iran. Ind. Crops Prod. 2019, 134, 89-99. [CrossRef]

30. Sarıcaoglu, F.T.; Turhan, S. Physicochemical, antioxidant and antimicrobial properties of mechanically deboned chicken meat protein films enriched with various essential oils. Food Packag. Shelf Life 2020, 25, 100527. [CrossRef]

31. Badhani, B.; Sharma, N.; Kakkar, R. Gallic acid: A versatile antioxidant with promising therapeutic and industrial applications. RSC Adv. 2015, 5, 27540-27557. [CrossRef]

32. Enache, T.A.; Oliveira-Brett, A.M. Phenol and para-substituted phenols electrochemical oxidation pathways. J. Electroanal. Chem. 2011, 655, 9-16. [CrossRef]

33. López-Alarcón, C.; Denicola, A. Evaluating the antioxidant capacity of natural products: A review on chemical and cellular-based assays. Anal. Chim. Acta 2013, 763, 1-10. [CrossRef]

34. Ledward, D.A. Metmyoglobin Formation in Beef Stored in Carbon Dioxide Enriched and Oxygen Depleted Atmospheres. J. Food Sci. 1970, 35, 33-37. [CrossRef]

35. Rukunudin, I.H.; White, P.J.; Bern, C.J.; Bailey, T.B. A modified method for determining free fatty acids from small soybean oil sample sizes. JAOCS J. Am. Oil Chem. Soc. 1998, 75, 563-568. [CrossRef]

36. Amorati, R.; Foti, M.C.; Valgimigli, L. Antioxidant activity of essential oils. J. Agric. Food Chem. 2013, 61, 10835-10847. [CrossRef] [PubMed]

37. Shahidi, F.; Ambigaipalan, P. Phenolics and polyphenolics in foods, beverages and spices: Antioxidant activity and health effects-A review. J. Funct. Foods 2015, 18, 820-897. [CrossRef]

38. Robertson, T.R.; Hamza, M.F. Paper Products: Food Packages. Ref. Modul. Mater. Sci. Mater. Eng. 2016. [CrossRef]

39. Buendía-Moreno, L.; Soto-Jover, S.; Ros-Chumillas, M.; Antolinos, V.; Navarro-Segura, L.; Sánchez-Martínez, M.J.; Martínez-Hernández, G.B.; López-Gómez, A. Innovative cardboard active packaging with a coating including encapsulated essential oils to extend cherry tomato shelf life. LWT 2019, 116, 108584. [CrossRef]

40. Muratore, F.; Barbosa, S.E.; Martini, R.E. Development of bioactive paper packaging for grain-based food products. Food Packag. Shelf Life 2019, 20, 100317. [CrossRef]

41. Sánchez-González, L.; Cháfer, M.; Chiralt, A.; González-Martínez, C. Physical properties of edible chitosan films containing bergamot essential oil and their inhibitory action on Penicillium italicum. Carbohydr. Polym. 2010, 82, 277-283. [CrossRef]

42. Sánchez-González, L.; Chiralt, A.; González-Martínez, C.; Cháfer, M. Effect of essential oils on properties of film forming emulsions and films based on hydroxypropylmethylcellulose and chitosan. J. Food Eng. 2011, 105, 246-253. [CrossRef]

43. Bonilla, J.; Atarés, L.; Vargas, M.; Chiralt, A. Effect of essential oils and homogenization conditions on properties of chitosan-based films. Food Hydrocoll. 2012, 26, 9-16. [CrossRef]

44. Gómez-Estaca, J.; de Lacey López, A.; López-Caballero, M.E.; Gómez-Guillén, M.C.; Montero, P. Biodegradable gelatin-chitosan films incorporated with essential oils as antimicrobial agents for fish preservation. Food Microbiol. 2010, 27, 889-896. [CrossRef]

45. Debiagi, F.; Kobayashi, R.K.T.; Nakazato, G.; Panagio, L.A.; Mali, S. Biodegradable active packaging based on cassava bagasse, polyvinyl alcohol and essential oils. Ind. Crops Prod. 2014, 52, 664-670. [CrossRef]

46. Wen, P.; Zhu, D.-H.; Wu, H.; Zong, M.-H.; Jing, Y.-R.; Han, S.-Y. Encapsulation of cinnamon essential oil in electrospun nanofibrous film for active food packaging. Food Control 2016, 59, 366-376. [CrossRef]

47. Zhou, Y.; Miao, X.; Lan, X.; Luo, J.; Luo, T.; Zhong, Z.; Gao, X.; Mafang, Z.; Ji, J.; Wang, H.; et al. Angelica Essential Oil Loaded Electrospun Gelatin Nanofibers for Active Food Packaging Application. Polymers 2020, 12, 299. [CrossRef] [PubMed]

48. Fuenmayor, C.A.; Mascheroni, E.; Cosio, M.S.; Piergiovanni, L.; Benedetti, S.; Ortenzi, M.; Schiraldi, A.; Mannino, S. Encapsulation of R-(+)-limonene in edible electrospun nanofibers. Chem. Eng. Trans. 2013, 32, 1771-1776. [CrossRef]

49. Joven, R.; Garcia, A.; Arias, A.; Medina, J. Development of an active thermoplastic film with oxygen scavengers made of activated carbon and sodium erythorbate. Packag. Technol. Sci. 2015, 28, 113-121. [CrossRef]

50. Ribeiro-Santos, R.; Andrade, M.; Sanches-Silva, A. Application of encapsulated essential oils as antimicrobial agents in food packaging. Curr. Opin. Food Sci. 2017, 14, 78-84. [CrossRef]

51. Pathak, C.; Vaidya, F.U.; Pandey, S.M. Mechanism for Development of Nanobased Drug Delivery System. In Applications of Targeted Nano Drugs and Delivery Systems; Elsevier: Amsterdam, The Netherlands, 2019; pp. 35-67.

52. Mohammadi, A.; Jafari, S.M.; Esfanjani, A.F.; Akhavan, S. Application of nano-encapsulated olive leaf extract in controlling the oxidative stability of soybean oil. Food Chem. 2016, 190, 513-519. [CrossRef]

53. Peng, X.Q.; Wei, M.J.; Wang, L.; Gu, L.P. Study on microcrystalline chitin cinnamon nanoemulsion. Appl. Mech. Mater. 2014, 525, 53-57. [CrossRef]

54. Severino, R.; Ferrari, G.; Vu, K.D.; Donsì, F.; Salmieri, S.; Lacroix, M. Antimicrobial effects of modified chitosan based coating containing nanoemulsion of essential oils, modified atmosphere packaging and gamma irradiation against Escherichia coli O157:H7 and Salmonella Typhimurium on green beans. Food Control 2015, 50, 215-222. [CrossRef] 
55. Mohsenabadi, N.; Rajaei, A.; Tabatabaei, M.; Mohsenifar, A. Physical and antimicrobial properties of starch-carboxy methyl cellulose film containing rosemary essential oils encapsulated in chitosan nanogel. Int. J. Biol. Macromol. 2018, 112, 148-155. [CrossRef]

56. Yao, Z.-C.; Chang, M.-W.; Ahmad, Z.; Li, J.-S. Encapsulation of rose hip seed oil into fibrous zein films for ambient and on demand food preservation via coaxial electrospinning. J. Food Eng. 2016, 191, 115-123. [CrossRef]

57. Sapper, M.; Wilcaso, P.; Santamarina, M.P.; Roselló, J.; Chiralt, A. Antifungal and functional properties of starch-gellan films containing thyme (Thymus zygis) essential oil. Food Control 2018, 92, 505-515. [CrossRef]

58. Silva, F.; Caldera, F.; Trotta, F.; Nerín, C.; Domingues, F.C. Encapsulation of coriander essential oil in cyclodextrin nanosponges: A new strategy to promote its use in controlled-release active packaging. Innov. Food Sci. Emerg. Technol. 2019, 56, 102177. [CrossRef]

59. Zinoviadou, K.G.; Koutsoumanis, K.P.; Biliaderis, C.G. Physico-chemical properties of whey protein isolate films containing oregano oil and their antimicrobial action against spoilage flora of fresh beef. Meat Sci. 2009, 82, 338-345. [CrossRef] [PubMed]

60. Negi, P.S. Plant extracts for the control of bacterial growth: Efficacy, stability and safety issues for food application. Int. J. Food Microbiol. 2012, 156, 7-17. [CrossRef]

61. Goñi, P.; López, P.; Sánchez, C.; Gómez-Lus, R.; Becerril, R.; Nerín, C. Antimicrobial activity in the vapour phase of a combination of cinnamon and clove essential oils. Food Chem. 2009, 116, 982-989. [CrossRef]

62. Coelho, P.M.; Corona, B.; ten Klooster, R.; Worrell, E. Sustainability of reusable packaging-Current situation and trends. Resour. Conserv. Recycl. X 2020, 6, 100037. [CrossRef]

63. Jeya Jeevahan, J.; Chandrasekaran, M.; Venkatesan, S.P.; Sriram, V.; Britto Joseph, G.; Mageshwaran, G.; Durairaj, R.B. Scaling up difficulties and commercial aspects of edible films for food packaging: A review. Trends Food Sci. Technol. 2020, 100, 210-222. [CrossRef]

64. European Commission. Regulation (EC) No 450/2009 of 29 May 2009 on active and intelligent materials and articles intended to come into contact with food. Off. J. Eur. Commun. 2009, 135, 3-11.

65. Acevedo-Fani, A.; Salvia-Trujillo, L.; Rojas-Graü, M.A.; Martín-Belloso, O. Edible films from essential-oil-loaded nanoemulsions: Physicochemical characterization and antimicrobial properties. Food Hydrocoll. 2015, 47, 168-177. [CrossRef]

66. Rehman, A.; Jafari, S.M.; Aadil, R.M.; Assadpour, E.; Randhawa, M.A.; Mahmood, S. Development of active food packaging via incorporation of biopolymeric nanocarriers containing essential oils. Trends Food Sci. Technol. 2020, 101, 106-121. [CrossRef]

67. García-Moreno, P.J.; Stephansen, K.; van der Kruijs, J.; Guadix, A.; Guadix, E.M.; Chronakis, I.S.; Jacobsen, C. Encapsulation of fish oil in nanofibers by emulsion electrospinning: Physical characterization and oxidative stability. J. Food Eng. 2016, 183, 39-49. [CrossRef]

68. Adel, A.M.; Ibrahim, A.A.; El-Shafei, A.M.; Al-Shemy, M.T. Inclusion complex of clove oil with chitosan/ $\beta$-cyclodextrin citrate/oxidized nanocellulose biocomposite for active food packaging. Food Packag. Shelf Life 2019, 20, 100307. [CrossRef]

69. Alparslan, Y.; Yapici, H.H.; Metin, C.; Baygar, T.; Günlü, A.; Baygar, T. Quality assessment of shrimps preserved with orange leaf essential oil incorporated gelatin. LWT Food Sci. Technol. 2016, 72, 457-466. [CrossRef]

70. Hosseini, S.F.; Rezaei, M.; Zandi, M.; Ghavi, F.F. Effect of Fish Gelatin Coating Enriched with Oregano Essential Oil on the Quality of Refrigerated Rainbow Trout Fillet. J. Aquat. Food Prod. Technol. 2016, 25, 835-842. [CrossRef]

71. Azarifar, M.; Ghanbarzadeh, B.; Sowti khiabani, M.; Akhondzadeh basti, A.; Abdulkhani, A. The effects of gelatin-CMC films incorporated with chitin nanofiber and Trachyspermum ammi essential oil on the shelf life characteristics of refrigerated raw beef. Int. J. Food Microbiol. 2020, 318, 108493. [CrossRef]

72. Zhang, Y.; Zhou, L.; Zhang, C.; Show, P.L.; Du, A.; Fu, J.C.; Ashokkumar, V. Preparation and characterization of curdlan/polyvinyl alcohol/ thyme essential oil blending film and its application to chilled meat preservation. Carbohydr. Polym. 2020, 247, 116670. [CrossRef]

73. Frazão, G.G.S.; Blank, A.F.; de Aquino Santana, L.C.L. Optimisation of edible chitosan coatings formulations incorporating Myrcia ovata Cambessedes essential oil with antimicrobial potential against foodborne bacteria and natural microflora of mangaba fruits. LWT Food Sci. Technol. 2017, 79, 1-10. [CrossRef]

74. Dini, H.; Fallah, A.A.; Bonyadian, M.; Abbasvali, M.; Soleimani, M. Effect of edible composite film based on chitosan and cumin essential oil-loaded nanoemulsion combined with low-dose gamma irradiation on microbiological safety and quality of beef loins during refrigerated storage. Int. J. Biol. Macromol. 2020, 164, 1501-1509. [CrossRef]

75. Lekjing, S. A chitosan-based coating with or without clove oil extends the shelf life of cooked pork sausages in refrigerated storage. Meat Sci. 2016, 111, 192-197. [CrossRef]

76. Sangsuwan, J.; Pongsapakworawat, T.; Bangmo, P.; Sutthasupa, S. Effect of chitosan beads incorporated with lavender or red thyme essential oils in inhibiting Botrytis cinerea and their application in strawberry packaging system. LWT Food Sci. Technol. 2016, 74, 14-20. [CrossRef]

77. Esmaeili, H.; Cheraghi, N.; Khanjari, A.; Rezaeigolestani, M.; Basti, A.A.; Kamkar, A.; Aghaee, E.M. Incorporation of nanoencapsulated garlic essential oil into edible films: A novel approach for extending shelf life of vacuum-packed sausages. Meat Sci. 2020, 166, 108135. [CrossRef] [PubMed]

78. Seydim, A.C.; Sarikus-Tutal, G.; Sogut, E. Effect of whey protein edible films containing plant essential oils on microbial inactivation of sliced Kasar cheese. Food Packag. Shelf Life 2020, 26, 100567. [CrossRef] 
79. Alizadeh Sani, M.; Ehsani, A.; Hashemi, M. Whey protein isolate/cellulose nanofibre/TiO2 nanoparticle/rosemary essential oil nanocomposite film: Its effect on microbial and sensory quality of lamb meat and growth of common foodborne pathogenic bacteria during refrigeration. Int. J. Food Microbiol. 2017, 251, 8-14. [CrossRef]

80. Xiong, Y.; Li, S.; Warner, R.D.; Fang, Z. Effect of oregano essential oil and resveratrol nanoemulsion loaded pectin edible coating on the preservation of pork loin in modified atmosphere packaging. Food Control 2020, 114, 107226. [CrossRef]

81. Guerreiro, A.C.; Gago, C.M.L.; Faleiro, M.L.; Miguel, M.G.C.; Antunes, M.D.C. The effect of alginate-based edible coatings enriched with essential oils constituents on Arbutus unedo L. fresh fruit storage. Postharvest Biol. Technol. 2015, 100, $226-233$. [CrossRef]

82. Noori, S.; Zeynali, F.; Almasi, H. Antimicrobial and antioxidant efficiency of nanoemulsion-based edible coating containing ginger (Zingiber officinale) essential oil and its effect on safety and quality attributes of chicken breast fillets. Food Control 2018, 84, 312-320. [CrossRef]

83. Murmu, S.B.; Mishra, H.N. The effect of edible coating based on Arabic gum, sodium caseinate and essential oil of cinnamon and lemon grass on guava. Food Chem. 2018, 245, 820-828. [CrossRef]

84. Jafarzadeh, S.; Jafari, S.M.; Salehabadi, A.; Nafchi, A.M.; Uthaya Kumar, U.S.; Khalil, H.P.S.A. Biodegradable green packaging with antimicrobial functions based on the bioactive compounds from tropical plants and their by-products. Trends Food Sci. Technol. 2020, 100, 262-277. [CrossRef]

85. Friedman, M.; Henika, P.R.; Mandrell, R.E. Bactericidal activities of plant essential oils and some of their isolated constituents against Campylobacter jejuni, Escherichia coli, Listeria monocytogenes, and Salmonella enterica. J. Food Prot. 2002, 65, 1545-1560. [CrossRef]

86. Fernández-Pan, I.; Carrión-Granda, X.; Maté, J.I. Antimicrobial efficiency of edible coatings on the preservation of chicken breast fillets. Food Control 2014, 36, 69-75. [CrossRef]

87. Friedman, M.; Henika, P.R.; Levin, C.E.; Mandrell, R.E. Antibacterial activities of plant essential oils and their components against Escherichia coli O157:H7 and Salmonella enterica in apple juice. J. Agric. Food Chem. 2004, 52, 6042-6048. [CrossRef] [PubMed]

88. Otero, V.; Becerril, R.; Santos, J.A.; Rodríguez-Calleja, J.M.; Nerín, C.; García-López, M.L. Evaluation of two antimicrobial packaging films against Escherichia coli O157: H7 strains invitro and during storage of a Spanish ripened sheep cheese (Zamorano). Food Control 2014, 42, 296-302. [CrossRef]

89. Gómez-Estaca, J.; López-de-Dicastillo, C.; Hernández-Muñoz, P.; Catalá, R.; Gavara, R. Advances in antioxidant active food packaging. Trends Food Sci. Technol. 2014, 35, 42-51. [CrossRef]

90. Shankar, K.; Mehendale, H.M. Oxidative Stress. Encycl. Toxicol. Third Ed. 2014, 735-737. [CrossRef]

91. Lee, D.S. Antioxidative Packaging System; Elsevier Ltd.: Amsterdam, The Netherlands, 2013.

92. European Commission. Proposal for a Directive of the European Parliament and of the Council on the Reduction of the Impact of Certain Plastic Products on the Environment; European Commission: Brussels, Belgium, 2018.

93. Kumar, A.; Singh, P.; Gupta, V.; Prakash, B. Application of Nanotechnology to Boost the Functional and Preservative Properties of Essential Oils; Elsevier Inc.: Amsterdam, The Netherlands, 2020.

94. Dini, I. Use of Essential Oils in Food Packaging; Elsevier Inc.: Amsterdam, The Netherlands, 2016.

95. Tongnuanchan, P.; Benjakul, S.; Prodpran, T. Properties and antioxidant activity of fish skin gelatin film incorporated with citrus essential oils. Food Chem. 2012, 134, 1571-1579. [CrossRef]

96. Wang, L.; Heising, J.; Fogliano, V.; Dekker, M. Fat content and storage conditions are key factors on the partitioning and activity of carvacrol in antimicrobial packaging. Food Packag. Shelf Life 2020, 24, 100500. [CrossRef]

97. Bahmid, N.A.; Pepping, L.; Dekker, M.; Fogliano, V.; Heising, J. Using particle size and fat content to control the release of Allyl isothiocyanate from ground mustard seeds for its application in antimicrobial packaging. Food Chem. 2020, $308,125573$. [CrossRef]

98. Camo, J.; Beltrán, J.A.; Roncalés, P. Extension of the display life of lamb with an antioxidant active packaging. Meat Sci. 2008, 80, 1086-1091. [CrossRef]

99. Lorenzo, J.M.; Batlle, R.; Gómez, M. Extension of the shelf-life of foal meat with two antioxidant active packaging systems. LWT Food Sci. Technol. 2014, 59, 181-188. [CrossRef]

100. Kodal Coşkun, B.; Çalikoğlu, E.; Karagöz Emiroğlu, Z.; Candoğan, K. Antioxidant active packaging with soy edible films and oregano or thyme essential oils for oxidative stability of ground beef patties. J. Food Qual. 2014, 37, 203-212. [CrossRef]

101. Romani, V.P.; Prentice-Hernández, C.; Martins, V.G. Active and sustainable materials from rice starch, fish protein and oregano essential oil for food packaging. Ind. Crops Prod. 2017, 97, 268-274. [CrossRef]

102. Gómez-Estaca, J.; Montero, P.; Giménez, B.; Gómez-Guillén, M.C. Effect of functional edible films and high pressure processing on microbial and oxidative spoilage in cold-smoked sardine (Sardina pilchardus). Food Chem. 2007, 105, 511-520. [CrossRef]

103. Jouki, M.; Yazdi, F.T.; Mortazavi, S.A.; Koocheki, A. Quince seed mucilage films incorporated with oregano essential oil: Physical, thermal, barrier, antioxidant and antibacterial properties. Food Hydrocoll. 2014, 36, 9-19. [CrossRef]

104. Teixeira, B.; Marques, A.; Pires, C.; Ramos, C.; Batista, I.; Saraiva, J.A.; Nunes, M.L. Characterization of fish protein films incorporated with essential oils of clove, garlic and origanum: Physical, antioxidant and antibacterial properties. LWT Food Sci. Technol. 2014, 59, 533-539. [CrossRef]

105. Sebranek, J.G.; Sewalt, V.J.H.; Robbins, K.L.; Houser, T.A. Comparison of a natural rosemary extract and BHA/BHT for relative antioxidant effectiveness in pork sausage. Meat Sci. 2005, 69, 289-296. [CrossRef] [PubMed] 
106. Souza, V.G.L.; Pires, J.R.A.; Vieira, É.T.; Coelhoso, I.M.; Duarte, M.P.; Fernando, A.L. Activity of chitosan-montmorillonite bionanocomposites incorporated with rosemary essential oil: From in vitro assays to application in fresh poultry meat. Food Hydrocoll. 2019, 89, 241-252. [CrossRef]

107. Choulitoudi, E.; Ganiari, S.; Tsironi, T.; Ntzimani, A.; Tsimogiannis, D.; Taoukis, P.; Oreopoulou, V. Edible coating enriched with rosemary extracts to enhance oxidative and microbial stability of smoked eel fillets. Food Packag. Shelf Life 2017, 12, 107-113. [CrossRef]

108. Kykkidou, S.; Giatrakou, V.; Papavergou, A.; Kontominas, M.G.; Savvaidis, I.N. Effect of thyme essential oil and packaging treatments on fresh Mediterranean swordfish fillets during storage at $4{ }^{\circ} \mathrm{C}$. Food Chem. 2009, 115, 169-175. [CrossRef]

109. Jouki, M.; Mortazavi, S.A.; Yazdi, F.T.; Koocheki, A. Characterization of antioxidant-antibacterial quince seed mucilage films containing thyme essential oil. Carbohydr. Polym. 2014, 99, 537-546. [CrossRef]

110. Sharma, H.; Mendiratta, S.K.; Agrawal, R.K.; Gurunathan, K.; Kumar, S.; Singh, T.P. Use of various essential oils as bio preservatives and their effect on the quality of vacuum packaged fresh chicken sausages under frozen conditions. LWT Food Sci. Technol. 2017, 81, 118-127. [CrossRef]

111. Ayala-Zavala, J.F.; Silva-Espinoza, B.A.; Cruz-Valenzuela, M.R.; Leyva, J.M.; Ortega-Ramírez, L.A.; Carrazco-Lugo, D.K.; Pérez-Carlón, J.J.; Melgarejo-Flores, B.G.; González-Aguilar, G.A.; Miranda, M.R.A. Pectin-cinnamon leaf oil coatings add antioxidant and antibacterial properties to fresh-cut peach. Flavour Fragr. J. 2013, 28, 39-45. [CrossRef]

112. Hu, J.; Wang, X.; Xiao, Z.; Bi, W. Effect of chitosan nanoparticles loaded with cinnamon essential oil on the quality of chilled pork. LWT Food Sci. Technol. 2015, 63, 519-526. [CrossRef]

113. Xing, Y.; Li, X.; Xu, Q.; Yun, J.; Lu, Y.; Tang, Y. Effects of chitosan coating enriched with cinnamon oil on qualitative properties of sweet pepper (Capsicum annuum L.). Food Chem. 2011, 124, 1443-1450. [CrossRef]

114. Andevari, G.T.; Rezaei, M. Effect of gelatin coating incorporated with cinnamon oil on the quality of fresh rainbow trout in cold storage. Int. J. Food Sci. Technol. 2011, 46, 2305-2311. [CrossRef]

115. Ojagh, S.M.; Rezaei, M.; Razavi, S.H.; Hosseini, S.M.H. Effect of chitosan coatings enriched with cinnamon oil on the quality of refrigerated rainbow trout. Food Chem. 2010, 120, 193-198. [CrossRef]

116. Ribeiro-Santos, R.; Sanches-Silva, A.; Motta, J.F.G.; Andrade, M.; de Neves, I.A.; Teófilo, R.F.; de Carvalho, M.G.; de Melo, N.R Combined use of essential oils applied to protein base active food packaging: Study in vitro and in a food simulant. Eur. Polym. J. 2017, 93, 75-86. [CrossRef]

117. Xuntao, Z.; Schaich, K.; Chen, X.; Yam, K. Antioxidant Effects of Sesamol Released from Polymeric Films on Lipid Oxidation in Linoleic Acid and Oat Cereal. Packag. Technol. Sci. 2013, 29, 399-412. [CrossRef]

118. Moosavy, M.H.; Hassanzadeh, P.; Mohammadzadeh, E.; Mahmoudi, R.; Khatibi, S.A.; Mardani, K. Antioxidant and antimicrobial activities of essential oil of lemon (Citrus limon) peel in vitro and in a food model. J. Food Qual. Hazards Control 2017, 4, 42-48.

119. Sanchez-Gonzalez, L.; Pastor, C.; Vargas, M.; Chiralt, A.; Gonzalez-Martinez, C.; Chafer, M. Effect of hydroxypropylmethylcellulose and chitosan coatings with and without bergamot essential oil on quality and safety of cold-stored grapes. Postharvest Biol. Technol. 2011, 60, 57-63. [CrossRef]

120. Hari, N.; Francis, S.; Rajendran Nair, A.G.; Nair, A.J. Synthesis, characterization and biological evaluation of chitosan film incorporated with $\beta$-Carotene loaded starch nanocrystals. Food Packag. Shelf Life 2018, 16, 69-76. [CrossRef]

121. Assis, R.Q.; Pagno, C.H.; Costa, T.M.H.; Flôres, S.H.; de Rios, A.O. Synthesis of biodegradable films based on cassava starch containing free and nanoencapsulated $\beta$-carotene. Packag. Technol. Sci. 2018, 31, 157-166. [CrossRef]

122. López De Dicastillo, C.; Ares Pernas, A.; Castro López, M.D.M.; López Vilariño, J.M.; González Rodríguez, M.V. Enhancing the release of the antioxidant tocopherol from polypropylene films by incorporating the natural plasticizers lecithin, olive oil, or sunflower oil. J. Agric. Food Chem. 2013, 61, 11848-11857. [CrossRef] [PubMed]

123. Barbosa-Pereira, L.; Cruz, J.M.; Sendón, R.; Rodríguez Bernaldo de Quirós, A.; Ares, A.; Castro-López, M.; Abad, M.J.; Maroto, J.; Paseiro-Losada, P. Development of antioxidant active films containing tocopherols to extend the shelf life of fish. Food Control 2013, 31, 236-243. [CrossRef]

124. Zhu, X.; Lee, D.S.; Yam, K.L. Release property and antioxidant effectiveness of tocopherol-incorporated LDPE/PP blend films. Food Addit. Contam. Part A Chem. Anal. Control Expo. Risk Assess. 2012, 29, 461-468. [CrossRef]

125. Otero-Pazos, P.; Sendón, R.; Blanco-Fernandez, B.; Blanco-Dorado, S.; Alvarez-Lorenzo, C.; Concheiro, A.; Angulo, I.; Paseiro-Losada, P.; Rodríguez-Bernaldo de Quirós, A. Preparation of antioxidant active films based on chitosan: Diffusivity study of $\alpha$-tocopherol into food simulants. J. Food Sci. Technol. 2016, 53, 2817-2826. [CrossRef] [PubMed]

126. Lu, Q.Y.; Summanen, P.H.; Lee, R.P.; Huang, J.; Henning, S.M.; Heber, D.; Finegold, S.M.; Li, Z. Prebiotic Potential and Chemical Composition of Seven Culinary Spice Extracts. J. Food Sci. 2017, 82, 1807-1813. [CrossRef]

127. Carvalho, C.B.; Madrona, G.S.; Mitcha, J.G.; Valero, M.V.; Guerrero, A.; Da Silva Scapim, M.R.; Yamashita, F.; Do Prado, I.N. Effect of active packaging with oregano oil on beef burgers with low sodium content. Acta Sci. Technol. 2020, 42, 1-11. [CrossRef]

128. Camo, J.; Lorés, A.; Djenane, D.; Beltrán, J.A.; Roncalés, P. Display life of beef packaged with an antioxidant active film as a function of the concentration of oregano extract. Meat Sci. 2011, 88, 174-178. [CrossRef]

129. Wang, Y.; Xia, Y.; Zhang, P.; Ye, L.; Wu, L.; He, S. Physical Characterization and Pork Packaging Application of Chitosan Films Incorporated with Combined Essential Oils of Cinnamon and Ginger. Food Bioprocess Technol. 2017, 10, 503-511. [CrossRef]

130. Ma, Q.; Zhang, Y.; Critzer, F.; Davidson, P.M.; Zivanovic, S.; Zhong, Q. Physical, mechanical, and antimicrobial properties of chitosan films with microemulsions of cinnamon bark oil and soybean oil. Food Hydrocoll. 2015, 52, 533-542. [CrossRef] 
131. Wang, W.; Liu, Y.; Jia, H.; Liu, Y.X.; Zhang, H.; He, Z.; Ni, Y.H. Effects of Cellulose Nanofibers Filling and Palmitic Acid Emulsions Coating on the Physical Properties of Fish Gelatin Films. Food Biophys. 2017, 12, 23-32. [CrossRef]

132. Galus, S.; Kadzińska, J. Food applications of emulsion-based edible films and coatings. Trends Food Sci. Technol. 2015, 45, 273-283. [CrossRef]

133. European Commission. Regulation (EC) No 1130/2011 of 11 November 2011 amending Annex III to Regulation (EC) No 1333/2008 of the European Parliament and of the Council on food additives by establishing a Union list of food additives approved for use in food additives, foodenzymes, food flavourings and nutrients. Off. J. Eur. Commun. 2011, 295, 178-204.

134. European Commission. Regulation (EC) No 1334/2008 of the European Parliament and of the Council of 16 December 2008 on flavourings and certain food ingredients with flavouring properties for use in and on foods and amending Council Regulation (EEC) No 1601/91. Off. J. Eur. Commun. 2008, 354, 34-50.

135. European Commission. Commission Implementing Regulation (EU) No 872/2012 of 1 October 2012 adopting the list of flavouring substances provided for by Regulation (EC) No 2232/96 of the European Parliament and of the Council, introducing it in Annex I to Regulation (EC) No 1334. Off. J. Eur. Commun. 2012, 267, 1-161.

136. European Food Safety Authority. European Compendium of botanicals reported to contain naturally occuring substances of possible concern for human health when used in food and food supplements. EFSA J. 2012. [CrossRef]

137. European Commission. Regulation (EC) No 178/2002 of the European Parliament and of the Council of 28 January 2002 laying down the general principles and requirements of food law, establishing the European Food Safety Authority and laying down procedures in matters of food safety. Off. J. Eur. Commun. 2002, 31, 1-24.

138. European Commission. Regulation (EC) No 1935/2004 of the European Parliament and of the Council of 27 October 2004 on materials and articles intended to come into contact with food and repealing Directives 80/590/EEC and 89/109/EEC. Off. J. Eur. Commun. 2004, 338, 4-17.

139. European Commission. Regulation (EC) No 2023/2006 of 22 December 2006 on good manufacturing practice for materials and articles intended to come into contact with food. Off. J. Eur. Commun. 2006, 50, 75-78.

140. Es, I.; Khaneghah, A.M.; Akbariirad, H. Global Regulation of Essential Oils. In Essential Oils in Food Processing: Chemistry, Safety and Applications; John Wiley \& Sons: New York, NY, USA, 2017; pp. 327-338.

141. Food and Drug Administration. Code of Federal Regulations. Part 182: Substances Generally Recognized as Safe; Food and Drug Administration: Washington, DC, USA, 2019; p. 3. 